\title{
Development of Vietnamese Medical Staff in the Period of Accelerated Industrialization and Modernization of the Country and International Integration
}

\author{
Do Thi Nhuong ${ }^{1} \&$ Chu Tuan Anh ${ }^{1}$ \\ ${ }^{1}$ Thai Nguyen University of Medicine and Pharmacy, Thai Nguyen, Vietnam \\ Correspondence: Chu Tuan Anh, Thai Nguyen University of Medicine and Pharmacy, No 284, Luong Ngoc \\ Quyen Street, Thai Nguyen, Vietnam.
}

Received: February 21, 2020

Accepted: March 17, 2020

Online Published: March 27, 2020

doi:10.20849/ajsss.v5i1.729

URL: https://doi.org/10.20849/ajsss.v5i1.729

\begin{abstract}
Medical staff holds a pivotal role in the Vietnamese health system, and is crucial to the efficiency and quality of health care services in Vietnam. It is their professional and dedicated work that is a permanent basis to guarantee protection of and care for people's health in the provision of health care services to people in all regions, including remote areas, borders and islands. The continuous growth in the quantity and quality of health workers in Vietnam has affirmed the right leadership of the Communist Party of Vietnam in building this health workforce over the years.
\end{abstract}

Keywords: Communist Party of Vietnam, medical staff, health workers, building, health care, health examination and treatment

\section{Introduction}

Medical staff plays an important role in the health sector because their activities are directly related to the lives of patients, the health of people, the quality of life, and the quality of human resources for Vietnam's renewal process. The medical staff in Vietnam currently operates in a wide range of fields, including both medical workers directly involved in health care for patients and those working in pharmaceutical manufacturing or preventive medicine (prevention and control of communicable diseases, unknown diseases, and social diseases; prevention and control of non-communicable diseases; school health; community nutrition; border health quarantine; activities of primary health care and health improvement for people in community; use of vaccines and medical bio-products; testing in preventive medicine, and biosafety in testing; state management of public services of preventive medicine). Medical staff consists of those who work at central hospitals, and are commune health workers or managers who undertake a heavy workload with 29 different jobs. Because of the importance of Vietnam's medical staff in the health care in particular and the development of society in general, the development of medical staff in Vietnam has always received attention of the Communist Party of Vietnam and the Government of Vietnam in training, recruiting, using and arranging health workers for the best possible outcome.

\section{The Views of the Communist Party of Vietnam on the Building of Medical Staff}

In the early years of the country's renewal from 1986, facing a serious shortage of health workers, the Communist Party of Vietnam had proper awareness of the position and importance of medical staff and considered it to be one of the important missions of the Party and the health sector. The leadership process of the Communist Party of Vietnam on building health workforce is a process of awareness, inquiry and innovation with open-minded thinking between theory and practice from time to time. Right at the Sixth Congress (1986), the Communist Party of Vietnam determined that: "The health of people and the future of our race is a matter of concern of the Party and State, is the responsibility of all sectors and unions, is also the responsibility and interest of each individual, etc. There is a need to promote scientific research, reform training and retraining of medical staff, and continuously develop the Vietnam's medicine and health; to afford to increase investment in health care and provide for the needs of health workers' physical and cultural life" (Communist Party of Vietnam, 2013). 
Facing the requirements of comprehensive health reform, the Communist Party of Vietnam has paid proper attention to the development of local medical staff. The Party affirmed that building this staff is to create self-reliant workforce for the health sector. Therefore, from the very early date, the Party issued Resolution No. 04-NQ/HNTW of the Fourth Conference of the Central Committee of the Party - Session VII (1993) on "urgent issues concerning people's health care and protection" such as: "Training medical staff in a structure consistent with and suitable for the development of health system in each stage, the education of medical ethics and service attitude, especially the tradition of "doctors as gentle mothers"; fostering knowledge and skills conformable to tasks as assigned; attaching importance to provide knowledge of disease prevention for health workers; taking care of the life of health workers; developing a salary policy that is commensurate with working characteristics; preventing and overcoming all negative behaviors in health examination and treatment, and health care; paying attention to the medical staff training in the orientation that sends this staff to take part in training programs for serving their institutions/facilities after returning; making appropriate policies to attract health workers to priority areas (Communist Party - "Documents of the Party on socio-economic development from the renewal (1986) to the present, 2017 ).

During the process accelerating industrialization and modernization of the country, the Ministry of Politics issued Resolution No. 46-NQ/TW dated 23 February 2005, addressing the work of protection, caring and improvement of people's health in the new situation", and affirmed: "Health is the most precious asset of every human being and the whole society. People's health protection, care and improvement are humanitarian activities, directly ensuring the human resources for the country's construction and defense, and must be one of the top priority policies of the Party and the State" (Communist Party of Vietnam, 2005).

In order to provide good health care, it is required to build a health network system including health workforce with some policies such as: "Rearranging the network, expanding and upgrading training institutions, meeting the demand for health workers in line with the development planning of health sector; building a number of medical staff training centers on par with advanced countries in the region; and strengthening the training of health workers under direct enrolment mechanism for the mountainous areas and the Mekong River Delta" (Communist Party of Vietnam, 2005).

In training and retraining, there should be a focus on the development of quantity associated with the improvement of clinical competence and medical ethics towards meeting the satisfaction of patients and the expectations of society. "Enhancing the training and development of health workforce both quantitatively and qualitatively; and improving the qualifications, responsibilities and medical ethics of health workers" (Communist Party of Vietnam - Documents of the 12th National Party Congress, 2017).

The arrangement and distribution of health workers receive much attention so that the staff members in the health sector can support and complement each other, limiting the shortage or redundancy of health workers in the regions, at the local areas, and in specialties which are difficult to attract recruits. "Implementing staff rotation program and encouraging doctors to work in mountainous, remote and disadvantaged areas" (Communist Party of Vietnam, 2005) is accompanied with "completing the planning, strengthening and upgrading the local health network system with doctors working at all medical stations in plain and midland communes, and most of mountainous villages; upgrading provincial and district hospitals as well as developing regional general hospitals in remote areas from the provincial center" (Communist Party of Vietnam, 2013). In the policy for health workers, there is a respect in the training, employment and treatment of medical talents. Additionally, there is an expansion to send highly qualified workers to train abroad with state funding and an offer to encourage self-training abroad by subjects in need as well.

One of the solutions to build health workforce is a remuneration policy that is consistent with the dedication. "Having a remuneration policy to make good use of health workers, especially in disadvantaged areas" (Communist Party of Vietnam (2013) is associated with "improving policies and salary regime for medical staff, especially in local and mountainous areas" (Communist Party of Vietnam (2013).

In recent years, people's health care needs have been increasingly diverse. People also have a different view of diseases and disease prevention, so they come to health institutions more often. The diverse and complicated structure of communicable and non-communicable diseases leads to an imbalance in the provision of health care services. Resolution No. 20-NQ / TW (2017) of the Sixth Conference of the 12th Central Committee of the Party on "strengthening the protection, caring and improvement of people's health in the new situation" showed breakthrough directing views: "Reforming fundamentally and comprehensively the work of medical staff training, meeting the requirements of both ethical and professional in conditions of proactive and positive international integration. Urgently perfecting legal provisions and implementing the framework of national 
education system, and the framework of national qualifications for medical staff training; promoting responsibilities and roles of hospitals in the building and development of university hospitals; implementing the remuneration for health workers. Determining the starting salary scale in accordance with the training time; having strong enough policies to encourage people with professional qualifications to work in remote and disadvantaged areas, borders and islands, and in the fields of preventive medicine, forensic medicine, mental illness, tuberculosis, leprosy, etc." (Communist Party of Vietnam (2017), Resolution No. 20-NQ/TW, 2017)

\section{The Specification of the Government of Vietnam and the Health Sector}

Implementing the Party's guidelines and policies, especially the thematic resolutions on people's health care, the Government and the Ministry of Health have concretized them with health thematic resolutions and programs, typically: Ordinance No. 07/2003/PL-UBTVQH11 of Standing Committee of the National Assembly dated February 25, 2003 on private medical and pharmaceutical practice; Law on Examination and Treatment 2009 of the National Assembly; Decision No. 35/2001/QD-TTg of the Prime Minister on the approval of "the Strategy for protection of and care for the people's health in the 2001-2010 period"; Decision No. 243/2005/QD-TTg on "the Government's Action Program on the implementation of the Politburo Resolution No. 46/NQ-TW dated February 23, 2005 on people's health protection, care and improvement in the new situation"; Decision No. 153/2006/QD-TTg dated June 30, 2006 of the Prime Minister, approving the Master Plan on development of Vietnam's health care system up to 2010 with a vision to 2020; Decision No. 1544/2007/QD-TTg of the Prime Minister on approving the Project on training of health workforce for disadvantaged and mountainous areas of provinces in the North and Central regions, the Mekong River Delta, and the Central Highlands according to the special recruitment; Decision No. 122 / QD-TTg (2013) of the Prime Minister on the approval of "the National Strategy for people's health protection, care and improvement in the 2011-2020 period, with a vision to 2030". These are the important legal bases for the health sector in practical circumstances.

Among the strategies and planning for its construction and development, the health sector in Vietnam has given priority to building medical staff, identifying this task as one of the principal missions for the development of the health sector. For example, "developing and issuing a master plan for the network of training institutions of health workers, a set of reasonable standard criterion and organization structure of health workforce to strengthen medical staff, improve the quality and efficiency of health care activities; arranging, expanding and upgrading training institutions, meeting the demand for quantity and quality of health workers in line with the development planning of the health sector; investing in facilities, equipment and qualified lecturers to meet the rapidly increasing quantity and quality of university pharmacists, nurses and midwives; ensuring a balanced health workforce structure in order to improve the effectiveness of the protection, caring and improvement of people's health; developing and proposing policies to recruit, train, use and treat talented people in the health sector; promoting to send health workers for abroad advanced training with state funding and foreign aid, as well as encouraging self-sufficient training; developing and proposing preferential policies for medical staff, especially local health workers and health workers serving in mountainous, remote, and disadvantaged areas, borders and islands" (Prime Minister, 2005).

\section{Principal Results and Discussions}

\subsection{Training, Retraining and Transferring of Medical Techniques}

The network of training institutions of medical staff has expanded significantly over the years. By 2014, there were 173 institutions for training health workers at all levels, in which there are 35 training institutions at university level, 44 training institutions at junior college level and 123 training institutions at post-secondary level (Ministry of Health, 2016). The system of medical staff training institutions has been reorganized and expanded nationwide with many forms of training to overcome the shortage of health workers, especially in disadvantaged and remote areas. The system of these institutions creates an abundant additional resource of medical staff. Nursing workforce is trained on a large scale at universities, junior colleges and post-secondary schools. The target of university, junior college, post-secondary nursing enrolment from over 11,000 people in 2006 and gradually increased to over 35,000 people in 2014 (Ministry of Health, 2016). The number of university graduates in medicine and pharmacy increased rapidly, with 13,391 students in 2016 compared to 7,987 students in 2010 (up 41.02\%) (Ministry of Health - Health Statistics Yearbook 2016, 2018). It can be presented in the following table: 
Table 1. Number of university graduates (Source: Ministry of Health, Health Statistics Yearbook 2010-2016)

\begin{tabular}{llllllll}
\hline Categories & Years & \multicolumn{7}{l}{2013} & 2014 & 2015 & 2016 \\
\cline { 2 - 8 } & 2010 & 2011 & 2012 & 2013 & & \\
\hline General doctor & 3.497 & 2.506 & 2.384 & 2.674 & 4.878 & 5.879 & 5.533 \\
\hline $\begin{array}{l}\text { Odontostomatology } \\
\text { doctor }\end{array}$ & 210 & 289 & 306 & 293 & 401 & 390 & 381 \\
\hline Traditional doctor & 362 & 98 & 154 & 349 & 862 & 1101 & 917 \\
\hline Pharmacist & 1.583 & 1.234 & 1.077 & 1.179 & 2.363 & 2.709 & 2.309 \\
\hline Nurse & 1.710 & 1.671 & 893 & 952 & 2.166 & 3.326 & 3.346 \\
\hline Medical technician & 233 & 236 & 97 & 399 & 659 & 972 & 728 \\
\hline Public health & 302 & 196 & 181 & 347 & 451 & 595 & 177 \\
\hline Total & 7.897 & 6.230 & 5.092 & 6.193 & 11.780 & 14.972 & 13.391 \\
\hline
\end{tabular}

Postgraduate training (Specialist I, Specialist II, Internship MD, Master and $\mathrm{PhD}$ ) in health care has been strengthened in all types of resources of highly qualified health workers for all levels, especially district and central hospitals. The number of postgraduates has increased over the years, especially in 2013 the number of postgraduates amounted to 13,080 (Ministry of Health, 2017).

Table 2. Number of postgraduates (Source: Health Statistics Yearbook, 2010-2016)

\begin{tabular}{llllllll}
\hline \multirow{2}{*}{ Categories } & \multicolumn{2}{l}{ Năm - Years } & \multicolumn{2}{l}{ 2013 } & 2014 & 2015 & 2016 \\
\cline { 2 - 8 } & 2010 & 2011 & 2012 & 2013 & & \\
\hline PhD & 143 & 179 & 119 & 954 & 146 & 117 & 84 \\
\hline Master & 954 & 950 & 972 & 3.448 & 1.200 & 1.474 & 1.457 \\
\hline Specialist degree 2 & 463 & 566 & 501 & 1525 & 644 & 650 & 662 \\
\hline Specialist degree 1 & 1.710 & 2.502 & 2.043 & 6.208 & 2.341 & 2.431 & 2.358 \\
\hline Internship MD & 117 & 257 & 166 & 945 & 277 & 342 & 303 \\
\hline Total & 3.387 & 4.454 & 3.801 & 13.080 & 4.608 & 5.014 & 4.864 \\
\hline
\end{tabular}

After 10 years of implementing the project "Sending professional medical staff from higher level hospitals to work in and support lower level hospitals with a view to improving quality of examination and treatment" according to Decision No. 1816/QD-BYT dated May 26, 2008 of the Minister of Health, there have been more than 4,000 central medical staff supporting lower level hospitals, transferring more than 4,800 medical techniques; 262 provincial hospitals sending 2,770 staff to support 200 hospitals, to organize 962 training courses for 20,443 health workers, and to transfer 2,514 medical techniques of 26 specialties to district hospitals; 305 district hospitals sending 3,234 doctors to 938 commune health stations, organizing 454 training courses for 3,976 health workers, and transferring 991 medical techniques and procedures to commune health stations. These results contribute to reducing the overcrowding at higher level hospitals and concurrently helping health workers at lower level hospitals master medical techniques without moving patients to central hospitals (Le Hoang, 2018).

\subsection{Quantity and Qualifications of Medical Staff}

The training, retraining and rotation of health workers in recent years together with the encouragement and support policies of the State have made a contribution to rapidly increasing the quantity and quality of medical staff. In 2004, Vietnam's health sector had 244,987 workers (Ministry of Health - Jahr 2009, 2010) and 38,404 workers by 2010 (Ministry of Health - Health Statistics Yearbook, 2012). Until 2016 it increased to 471,702 
workers (Ministry of Health - Health Statistics Yearbook, 2018). The medical staff has been strengthened at different levels and with different subjects, in which the number of doctors (graduates and postgraduates), post-secondary pharmacists and nurses has climbed quickly over the years.

Table 3: Health workers by years

\begin{tabular}{|c|c|c|c|c|c|c|c|c|}
\hline \multirow[t]{2}{*}{ Categories } & \multicolumn{8}{|l|}{ Years } \\
\hline & 2004 & 2006 & 2008 & 2010 & 2012 & 2014 & 2016 & 2018 \\
\hline $\begin{array}{l}\text { Medical doctors } \\
\& \text { higher }\end{array}$ & 48.15 & 52.413 & 56.208 & 62.546 & 65.135 & 70.362 & 79.306 & 84.400 \\
\hline $\begin{array}{l}\text { Assistant } \\
\text { doctors }\end{array}$ & 48.059 & 48.519 & 49.213 & 52.455 & 55.999 & 56.090 & 53.558 & 53.558 \\
\hline $\begin{array}{l}\text { Pharmacists \& } \\
\text { higher }\end{array}$ & 6.360 & 10.700 & 10.524 & 15.150 & 17.360 & 21.843 & 27.473 & - \\
\hline $\begin{array}{l}\text { Assistant } \\
\text { pharmacists \& } \\
\text { 2nd degree } \\
\text { pharm. } \\
\text { Technicians }\end{array}$ & 10.424 & 12.620 & 12.533 & 43.050 & 43.090 & 44.867 & 70.340 & - \\
\hline $\begin{array}{l}\text { High degree } \\
\text { nurses \& 2nd } \\
\text { degree nurses }\end{array}$ & 49.534 & 57.003 & 67.081 & 74.098 & 86.506 & 89.738 & 101.049 & $\begin{array}{l}107.59 \\
6\end{array}$ \\
\hline $\begin{array}{l}\text { Uni. \& 2nd } \\
\text { degree } \\
\text { midwives }\end{array}$ & 17.610 & 19.242 & 22.943 & 25.289 & 27.089 & 27.891 & 27.676 & - \\
\hline $\begin{array}{l}\text { Traditional } \\
\text { medicine } \\
\text { practitioners }\end{array}$ & 293 & 656 & 882 & 1.657 & 237 & 224 & 210 & - \\
\hline $\begin{array}{l}\text { Medical } \\
\text { technicians }\end{array}$ & 9.763 & 11317 & 15.682 & 14.987 & 15.711 & 17.052 & 18.671 & - \\
\hline Others & 64.516 & 70.395 & 64.915 & - & - & - & - & - \\
\hline Total & 244.987 & 271.149 & 299.100 & 382.404 & 407.148 & 430.496 & 471.702 & - \\
\hline
\end{tabular}

Note: + Number of health workers from 2004 to 2008 from Ministry of Health - Jahr 2009; + Number of health workers from 2010 to 2016 from Ministry of Health - Health Statistics Yearbook, 2010-2016 ; + Number of health workers since 2010 from General Statistics Office of Vietnam, 2019

The number of doctors per 10,000 people showed an upward trend. In 2010, there were 7.2 doctors and 1.76 university pharmacists per 10,000 people (Ministry of Health - Health Statistics Yearbook, 2010 and 2012, p.52) and in 2018 this number reached 8.6 doctors and 2.96 university pharmacists per 10,000 people (General Statistics Office of Vietnam, 2019).

\subsection{Distribution of Medical Staff}

To implement the National Strategy for the protection, caring and improvement of people's health and the overall planning of Vietnam's health care system, with the aim of reforming and perfecting this system, and setting up appropriate levels of health care institutions, there were a significant increase of graduate health workers at commune and district levels. The total number of doctors at commune health stations in 2010 was 7,439 people (Ministry of Health - Health Statistics Yearbook, 2010 and 2012), in 2014 was 8,409 people (Ministry of Health Health Statistics Yearbook, 2014 and 2016), in 2016 was 9,226 people (Ministry of Health - Health Statistics Yearbook, 2016 and 2018). The number of district doctors increased from 14,942 in 2010 (Ministry of Health Health Statistics Yearbook, 2010 and 2012) to 18,770 in 2014 (Ministry of Health - Health Statistics Yearbook, 2014 and 2016) and 21,574 people in 2016 (Ministry of Health - Health Statistics Yearbook, 2016 and 2018). 
At commune level, $76.9 \%$ of commune health stations had doctors in 2013, including commune health stations with doctors who worked more than 3 days per week). In the mountainous areas of the North and the Central Highlands, the Mekong Delta, especially in some mountainous and remote districts, this proportion is lower (Ministry of Health - Jahr 2015 and 2016).

In addition, specialized and high-tech medical techniques are also encouraged to be implemented in order to overcome the overcrowding at central and provincial hospitals and to meet the modernization requirements in the health sector.

A number of specialties and local health care institutions having difficulty in recruiting health workers have also been supported by the State and the health sector. A number of policies and projects have been issued and implemented such as the Decision No. 319/QD-TTg (2013) of the Prime Minister approving the project to encourage training and development of health workers for tuberculosis, leprosy, mental illness, forensic medicine, and pathology surgery in the 2013-2020 period; the pilot project to send young volunteer doctors to work in mountainous and remote areas, borders, islands, or any regions with difficult socio-economic conditions (priority is given to 62 poor districts) according to the Decision No. 585/QD-BYT implemented and by 2016 there were about 500 young doctors working in these areas.

\section{Shortcomings and Limitations}

\subsection{Training of Medical Staff}

The training of medical staff is still mainly based on the stature and assurance of medical facilities. The training program has not been effectively implemented due to limitations in guidance, monitoring, supervision and evaluation. It also has not integrated with the world in terms of the training approach, methods and content.

Observation results from 44 medical facilities show that many large-scale training universities ( 5 universities with more than 2 thousand students each) but the number of postgraduate lecturers are still not high ( $42 \%$ of universities have under $20 \%$ of graduate lecturers). The results from 10 universities on training according to other ways of enrolment showed that the number of candidates of special enrolment mechanism and inter-college program of general health, and inter-college program of pharmacy accounted for a large proportion (Ministry of Health -Jahr 2015, 2016).

Currently, the Ministry of Health does not have a standard 18-month internship program in hospitals for doctors after their graduation from medical universities to be eligible for professional certificates in accordance with the Law on Examination and Treatment. Therefore, there has not been a connection between continuous training activities and professional certificate achievement.

\subsection{Quality and Distribution of Medical Staff}

The medical staff, especially at commune level, still lacks competence in first aid, diagnosis and treatment of some diseases, as well as in-depth knowledge on disease. According to a research in mountainous areas, only $17.3 \%$ of doctors and physicians interviewed had the right knowledge and skills in first aid management, $17 \%$ acknowledged the signs of danger during pregnancy, $50.5 \%$ knew how to diagnose hypertension and $15.6 \%$ knew how to manage a disease outbreak, etc. (Ministry of Health - Jahr 2015, 2016).

The distribution of health workers is still inadequate. Although there have been changes in recruitment and workforce distribution, there are still many shortcomings. There is a disparity in the quantity and quality of health workers between treatment and preventive medicine, among specialties, between the central and local levels.

The distribution of health workers is unreasonable among geographic areas, between urban and rural areas, especially in mountainous areas. Currently, graduate and postgraduate health workers are concentrated in cities and developed economic areas. Now, $56.6 \%$ of graduate and postgraduate health workers are at central and provincial hospitals (Table 4 ) while $43.4 \%$ at district and commune levels.

At local level, $43.9 \%$ of doctors and $48.3 \%$ of pharmacists work at provincial hospitals, $30.8 \%$ of doctors and $31.3 \%$ of pharmacists work at district hospitals, $12.6 \%$ of doctors and $2.2 \%$ of pharmacists work at commune health stations (Table 4). 
Table 4. Health worker distribution in urban and rural areas in 2016

\begin{tabular}{|c|c|c|c|c|c|c|c|c|c|c|}
\hline \multirow{3}{*}{ Categories } & \multicolumn{4}{|c|}{ Urban area } & \multicolumn{4}{|c|}{ Rural area } & \multirow{2}{*}{\multicolumn{2}{|c|}{ Total number }} \\
\hline & \multicolumn{2}{|c|}{ Central } & \multicolumn{2}{|c|}{ Provincial } & \multicolumn{2}{|l|}{ District } & \multicolumn{2}{|c|}{ Commnue } & & \\
\hline & No. & $\%$ & No. & $\%$ & No. & $\%$ & No. & $\%$ & No. & $\%$ \\
\hline $\begin{array}{ll}\text { Medical } & \\
\text { doctors } \quad \& \\
\text { higher }\end{array}$ & 9.489 & $12,7 \%$ & 32.890 & $43,9 \%$ & 23.048 & $30,8 \%$ & 9.422 & $12,6 \%$ & 74.849 & $100 \%$ \\
\hline $\begin{array}{l}\text { Assistant } \\
\text { doctors }\end{array}$ & 225 & $0,4 \%$ & 8.028 & $15,5 \%$ & 16.834 & $32,4 \%$ & 26.855 & $51,7 \%$ & 51.942 & $100 \%$ \\
\hline $\begin{array}{l}\text { Pharmacists } \\
\& \text { higher }\end{array}$ & 1.295 & $18,1 \%$ & 3.454 & $48,3 \%$ & 2.240 & $31,3 \%$ & 160 & $2,2 \%$ & 7.149 & $100 \%$ \\
\hline $\begin{array}{l}\text { Assistant } \\
\text { pharmacists } \\
\& 2 \text { nd degree } \\
\text { pharm }\end{array}$ & 743 & $3,5 \%$ & 6.770 & $31,9 \%$ & 7.157 & $33,8 \%$ & 6.523 & $30,8 \%$ & 21.193 & $100 \%$ \\
\hline $\begin{array}{l}\text { High } \\
\text { degree } \\
\text { nurses \& 2nd } \\
\text { degree } \\
\text { nurses }\end{array}$ & 9.166 & $9,2 \%$ & 47.922 & $48,0 \%$ & 29.651 & $29,7 \%$ & 13.089 & $13,1 \%$ & 99.828 & $100 \%$ \\
\hline $\begin{array}{l}\text { Uni. \& 2nd } \\
\text { degree } \\
\text { midwives }\end{array}$ & 647 & $2,4 \%$ & 6.917 & $25,4 \%$ & 8.688 & $31,9 \%$ & 10.990 & $40,3 \%$ & 27.242 & $100 \%$ \\
\hline $\begin{array}{l}\text { Medical } \\
\text { technicians } \\
\text { degree \& } \\
\text { higher }\end{array}$ & 2.031 & $11,9 \%$ & 9.053 & $53,1 \%$ & 5.690 & $33,4 \%$ & 278 & $1,6 \%$ & 17.052 & $100 \%$ \\
\hline $\begin{array}{l}\text { Elementary } \\
\text { pharmacists }\end{array}$ & 26 & $2,5 \%$ & 398 & $37,9 \%$ & 314 & $29,9 \%$ & 312 & $29,7 \%$ & 1.050 & $100 \%$ \\
\hline $\begin{array}{l}\text { Traditional } \\
\text { medicine } \\
\text { practitioners }\end{array}$ & 67 & $32,4 \%$ & 49 & $23,7 \%$ & 43 & $20,8 \%$ & 48 & $23,2 \%$ & 207 & $100 \%$ \\
\hline $\begin{array}{l}\text { Master and } \\
\text { Other } \\
\text { bachelor } \\
\text { degrees }\end{array}$ & 5.739 & $22,6 \%$ & 11.667 & $46,0 \%$ & 7.719 & $30,5 \%$ & 214 & $0,8 \%$ & 25.339 & $100 \%$ \\
\hline $\begin{array}{l}\text { Other 2nd } \\
\text { degree level }\end{array}$ & - & - & 5.517 & $47,0 \%$ & 5.312 & $45,3 \%$ & 908 & $7,7 \%$ & 11.737 & $100 \%$ \\
\hline $\begin{array}{l}\text { Population } \\
\text { officer }\end{array}$ & - & - & 52 & $5,7 \%$ & 208 & $22,8 \%$ & 653 & $71,5 \%$ & 913 & $100 \%$ \\
\hline
\end{tabular}

* Note: This is a distribution according to urban and rural areas without considering health workers in other fields, so the data is different from Table 3.

The number of graduate pharmacists in Hanoi and Ho Chi Minh City accounts for more than $48 \%$ of the total number of pharmacists in the country. The majority (92\%) of these pharmacists work in the private health sector, making up more than half of all private pharmacists in the country (Ministry of Health, Health Statistics Yearbook 2014 , 2016). At provincial general hospitals, the number of graduate pharmacists comprises only $19.6 \%$ of the total pharmacist workforce (Ministry of Health -Jahr 2015, 2016). 
The ratio of doctors per ten thousand people nationwide has increased steadily, and in some areas it is quite high, but in some provinces of the Mekong Delta and Southeast, this rate is still low (Ministry of Health -Jahr 2015 and 2016).

There is still an unreasonable distribution among departments within a hospital; some departments such as infectious and tropical departments and

psychiatry departments lack doctors.

At present, about $50 \%$ of village midwives have not been employed in the health care system and have a monthly allowance. Health workers' performance evaluation has not been used as an effective management tool as a basis for rewarding or punishment, and thus it has not created a motivation for health workers (Ministry of Health - Jahr 2015 and 2016).

\subsection{Planning and Remuneration Policy}

The planning and management of health workforce at all levels remain limited. The monitoring and administration of this workforce has not been standardized. Moreover, there should be more adequate, accurate and specific information on human resources for health.

The remuneration for health workers is not appropriate; particularly salaries and allowances are low, not commensurate with long-term training, heavy workload, and strenuous, toxic, dangerous working environment and conditions, especially in mountainous and rural areas. Along with limitations in health care service capacity, negative phenomena in health sector in some places are a serious concern and pressing issue of the society.

"About $80 \%$ of health workers interviewed earn monthly income mainly from salaries and allowances; more than half of these (43.2\%) have only salaries and allowances without any additional income. Thus, up to $73.5 \%$ said that the monthly income at work only ensures a part of their needs of life. Especially, about one fourth (24.2\%) frankly commented that the current income is insignificant compared to the expenses. Nearly one third of health workers surveyed had to work overtime, of which only $42 \%$ worked overtime by their professional job, the remaining of $58 \%$ had to do non-professional jobs. In spite of living on many ways, health workers still receive an overtime pay lower than their income at work. These are potential risk factors for brain drain from lower levels to upper levels, from public to non-public" (Vu Thi Minh Hanh, Vu The Hung, 2011).

\section{Recommendations and Solutions}

Practically, in order to complete the given task and achieve success in the National Strategy for protection, caring and improvement of people's health, contributing to the decision on building and renewing the health sector, and meeting the requirements for social needs, it is necessary to focus on the following:

Firstly, strengthening the leadership in building health workforce.

In the coming time, the Party Committees at all levels continue to promote their roles and responsibilities in building the medical staff and organizing the effective implementation of the Party's policies of human resources in the new period; to vigorously renew and synchronously deploy guidelines and measures for staff work; and to build qualified medical staff to meet the requirements of medical tasks and people's health care.

In order to build health workforce to meet social requirements, it is necessary to develop a thematic resolution of the Party on health workers, because up to now, there have not been a specialized resolution on building medical staff integrated in Resolution 20-NQ/TW of the Politburo or Resolutions of the Party Congress or Resolution on building intellectual staff, etc.

Secondly, promoting the management and advisory role of the Government and the health sector for the Party's staff work.

The development of health workforce needs to be linked with national programs and goals in the field of health care. The Government should promulgate policies on salaries and allowances for health workers in line with this specific field of work, as asserted in Resolution 20-NQ/TW.

The health sector should do more researching and forecasting on the needs of health workers in localities and fields, thereby advise the Party and the State to propose specific resolutions and programs, which are suitable for both short-term and long-term goals.

Thirdly, synchronously implementing solutions to improve the quality of training, retraining, recruitment and arrangement of health workers.

- Policy solutions: The Party Committees at all levels and the authorities need to formulate specific policies in recruiting and arranging health workers, especially at health care institution and in difficult recruiting fields. At the 
same time, there is an incentive and supporting policy suitable for health workers joining long-term or short-term training courses to improve their professional qualifications. The State should have preferential policies on salaries, allowances, career development opportunities and promotion opportunities for health workers in rural, mountainous and disadvantaged areas, and these policies need to be studied and put it into practice according to a long-term strategy. Additionally, it is necessary to develop the policies for the development of non-public health workers and take advantage of a number of other potential human resources.

- Training solutions: In the coming time, universities of medicine and pharmacy should continue researching and renewing training contents and programs according to Resolution No. 29-NQ/TW of the Central Conference 8 Session XI on fundamental and comprehensive renovation of education and training, to improve both quantity and quality in order to better meet the people's increasing health care requirements; investing in the state budget for new training, stepping up technical training and retraining in order to raise professional qualifications for lower-level health workers; increasing the capacity and upgrading the quality of training system to meet the increasing demand for health workers in both quantity and quality; expanding and balancing training scale by education levels and majors to meet the diverse needs of health workforce for the performance of preventive, curative, curative and functional rehabilitation tasks. The training scale and programs should meet the requirements of general medical workforce and health care according to the family doctor model, focus on health care for elderly people and social work. These are specialized fields with great demand in the medium and long term.

The training of doctors and health workers for commune health stations need to be emphasized so that they can carry out general medical practice activities, operate the family doctor model, implement health insurance policies and cover health care for all people. Besides, there are some encouragements to and supports for students in priority subjects and levels according to development their professional orientations, as well as some specialties with low attraction, little or no-market advantage. The training institutions may expand a number of fields such as family doctor and community-based health care, rehabilitation medicine and some high-tech specialties.

It is required to continue strengthening technology support and transfer so that lower-level health workers will be able to handle complex techniques so that patients can be treated without moving to higher levels.

- Finance solutions: The State need to develop financial policies, special remuneration, specific workforce targets and related conditions including increasing budget allocations, rural health allowances in order to collect attract, recruit and retain health workers in rural, mountainous and disadvantaged areas and create favorable conditions for them to work effectively. Appropriate remuneration policies should be built to limit the number of public health workers leaving their jobs and work at private health institutions with higher remuneration policies, resulting in a shortage of health workers in public health institutions.

- International cooperation solutions: The State needs to expand more international cooperation in professional training and retraining, to select qualified workers and students studying and experiencing advanced technologies and methods of health care and protection in the region and the world. Through international cooperation, the capacity of professional training and technology transfer, the scale of workforce management training and electronic training program system at central training institutions. There should be a priority in international cooperation for training highly qualified staff, principal specialties, hospital management and health economics.

\section{Conclusions}

Construction of medical staffs Vietnam special significance for the health sector, contributing to improving the quality of health care for the people. Ensuring the quantity and quality of health human resources is the most important mission to strengthen the capacity of health systems Vietnam in implementing its role community care. Therefore, in the construction of medical staff requires synchronously implement policy solutions for training, recruitment, use, encourage for this team. This is a problematic situation to be studied objectively, seriously to give a scientific basis to serve the activities of the health sector in the coming years.

\section{References}

Communist Party of Vietnam. (2005, February 23). Politburo Resolution No. 46/NQ-TW. People's health protection, care and improvement in the new situation.

Communist Party of Vietnam. (2013). Documents of the Party Congress in the period of renewal and integration (Congress VI, VII, VIII, IX, X, XI, pp. 72, 361, 418), National Political Publishing House, Hanoi.

Communist Party of Vietnam. (2017). Documents of the 12th National Party Congress (p.302). National Political Publishing House, Hanoi. 
Communist Party of Vietnam. (2017, October 25). Resolution No. 20-NQ/TW. The Sixth Conference of the $12^{\text {th }}$ Central Committee of the Party on "strengthening the protection, caring and improvement of people's health in the new situation. Retrieved from http://tulieuvankien.dangcongsan.vn/van-kien-tu-lieu-ve-dang/hoi-nghi-bch-trung-uong/khoa-xii/2019bao-5 70

Communist Party. (2017). Documents of the Party on socio-economic development from the renewal (1986) to the present (National Political Publishing House - Truth, Hanoi, 2014). Retrieved from http://dangcongsan.vn/tu-lieu-van-kien/tu-lieu-ve-dang/sach-chinh-tri/books-11520162411956/index-31520 16245085620.html

General Statistics Office of Vietnam. (2019). Statistical Summary Book (p.407). Statistical Publishing House.

Hanh, V. T. M., \& Hung, N. T. (2011). Analyzing the situation and proposing amending and supplementing a number of mechanisms of allowances for workers and employees in public health facilities. Journal of Health Policy, (8), 21-28.

Hoang, L. (2018). From Project 1816 to Satellite Hospital: Talking Numbers. Retrieved November 15, 2019, from

https://baotintuc.vn/van-de-quan-tam/tu-de-an-1816-den-benh-vien-ve-Tinh-velvet-the-number-knowing-no $-2017-20171210071712355 . h t m$

Ministry of Health. (2010). Jahr 2009 (p.49).

Ministry of Health. (2012). Health Statistics Yearbook 2010 (pp. 52, 54, 98, 99 \& 102). Medical Publishing House, Hanoi.

Ministry of Health. (2013). Health Statistics Yearbook 2011 (pp. 100, 101 \& 102). Medical Publishing House, Hanoi.

Ministry of Health. (2013). Health Statistics Yearbook 2012 (pp. 100, 101 \& 102). Medical Publishing House, Hanoi.

Ministry of Health. (2015). Health Statistics Yearbook 2013 (pp. 100, 101 \& 103). Medical Publishing House, Hanoi.

Ministry of Health. (2016). Health Statistics Yearbook 2014 (pp. 54, 56, 102 \& 103). Medical Publishing House, Hanoi.

Ministry of Health. (2016). Jahr 2015 (p.33, 37, 39, 40 \& 41).

Ministry of Health. (2017). Health Statistics Yearbook 2015 (pp. 105, 106 \& 107). Medical Publishing House, Hanoi.

Ministry of Health. (2018). Health Statistics Yearbook 2016 (pp. 56, 57, 58 \& 102). Medical Publishing House, Hanoi.

Prime Minister. (2005, February 23). Decision No. 243/2005/QD-TTg. The Government's Action Program on the implementation of the Politburo Resolution No. 46/NQ-TW on people's health protection, care and improvement in the new situation.

\section{Copyrights}

Copyright for this article is retained by the author(s), with first publication rights granted to the journal.

This is an open-access article distributed under the terms and conditions of the Creative Commons Attribution license (http://creativecommons.org/licenses/by/4.0/). 